Gut, 1966, 7, 624

\title{
Histochemical study of the effect of enzyme inhibitors on gastric secretion ${ }^{1}$
}

\author{
G. L. STOFFELS, W. GEPTS, AND J. J. DESNEUX \\ From the Departments of Pathology and Gastroenterology, \\ the University of Brussels and Queen Elizabeth Foundation, Brussels, Belgium
}

EDITORIAL COMMENT Inhibitors of sulphydryl enzymes are known to block gastric acid secretion. The effect of three such inhibitors on particular enzymes in the gastric mucosa, as demonstrated by histochemical methods, is described in this paper in an attempt to explain the mechanism by which acid secretion is blocked. Further work will be needed to decide whether these inhibitors act by blocking energy-producing systems or by inhibiting a specific enzyme system involved in the production of hydrogen ion.

There are many arguments in favour of the theory that the parietal cells of the gastric mucosa are primarily concerned in the secretion of hydrochloric acid. As yet the biochemical process of this secretion is unknown but there have been investigations into the effect of inhibition of one or more enzymes, employing specific enzyme inhibition techniques, on the secretion of hydrochloric acid. The effect of three specific inhibitors of sulphydryl enzymes has been studied by Davenport, Chavré, and Davenport $(1954,1955)$, with the result that p-chloromercuribenzoate, n-ethyl-maleimide, and iodoacetamide have been shown to inhibit the secretion of hydrochloric acid. Hollander (1956) has confirmed the inhibitory action of n-ethyl-maleimide and iodoacetamide on the secretion of hydrochloric acid in experiments with dogs having Heidenhain pouches. A similar inhibitory action has been demonstrated with antimycin A (a succinicoxidase inhibitor) by Davenport and Chavré (1956). These authors consider that the inhibition of acid secretion produced by these inhibitors is due to their effect on the enzymes of the parietal cells. However, the identity of the affected enzymes has not been determined. Although it is known that these reagents inhibit sulphydryldependent enzymes the effect may vary, depending on the origin of the latter.

The present histochemical study reports the effect of p-chloromercuribenzoate, n-ethyl-maleimide, and iodoacetamide on the enzymatic activity of the gastric mucosa of rats and attempts to correlate the findings with the blockage of acid secretion produced in vivo by these inhibitors.

${ }^{1}$ This investigation was supported by research grant 459 of the Fondation de la Recherche Scientifique Médicale Belge.

\section{MATERIALS AND METHODS}

HISTOCHEMICAL STUDY OF THE GASTRIC MUCOSA IN FED AND FASTING NORMAL RATS Gastric specimens from 15 rats following a 24-hour fast and from 15 rats fed ad libitum have been studied. All the specimens were taken at the same level of the gastric fundus, and were frozen at $-40^{\circ} \mathrm{C}$. by means of dry ice. Tissue sections $10 \mu$ thick were prepared in a cryostat and immediately investigated for lactic dehydrogenase (LDH), $\beta$-hydroxybutyric dehydrogenase $(\beta-\mathrm{BDH})$, succinic dehydrogenase (SDH), isocitric dehydrogenase (ICDH), glucose-6phosphate dehydrogenase (G-6PD) by the method of Nachlas, Tsou, De Souza, Cheng, and Seligman (1957), $\alpha$-glycerophosphate dehydrogenase ( $\alpha$-GPD) by the method of Wattenberg and Leong (1960); diphosphopyridine-nucleotide diaphorase (DPN) and triphosphopyridine-nucleotide diaphorase (TPN) by the method of Scarpelli, Hess, and Pearse (1958), mitochondrial adenosine triphosphatase (ATPase) by the method of Wachstein and Meisel (1957) as modified by Wachstein, Bradshaw, and Ortiz (1962); acid phosphatase (AcP) and alkaline phosphatase (AlkP) by the method of Gomori (1952); and non-specific esterase (Est $\alpha$ ) by the $\alpha$-naphthylacetate method of Pearse (1960).

EFFECT IN VITRO OF PCMB, IAA, AND NEM ON THE ENZYMES OF THE GASTRIC MUCOSA To investigate the effect in vitro of p-chloromercuribenzoate, iodoacetamide, and nethyl-maleimide on the above enzyme, we preincubated the sections with varying concentrations of these inhibitors for five minutes, or added them to the substrate (Table II). For preincubation inhibition, the inhibitors were dissolved in the same buffer as was used in the enzymatic staining reaction. However, in view of their instability in an acid medium, distilled water was used as a solvent for the study of their effect on AcP.

EFFECT OF INHIBITORS STUDIED ON ACID SECRETION OF THE STOMACH IN VIVO To investigate the gastric secretion 
following histamine challenge in living rats previously treated with one of the three inhibitors, we employed the technique of Thornton and Clifton (1959) as modified by Valberg and Wetts (1961). Forty-six rats were used for this part of the study. They had been fasted for 24 hours but received water ad libitum. The stomachs of all the rats were washed with saline immediately before starting the experiments. This investigation was subdivided into two series.

First series (10 rats) The stomach was filled by means of intubation with solution T (a preparation of Sorensen's phosphate buffer, $10 \mathrm{ml}$., at $p \mathrm{H} 8 \cdot 2$, with sucrose in a concentration of $15 \mathrm{~g} . / 1$.). The stomach was then washed, emptied, and filled again with solution $R(8 \mathrm{ml}$. of a solution of phenol red at $10 \mathrm{mg}$. $/ 100 \mathrm{ml}$. and sucrose at $15 \mathrm{~g} . / \mathrm{l}$.). At the same time histamine hydrochloride, $50 \mathrm{mg}$. $/ \mathrm{kg}$., was injected subcutaneously. After 45 minutes solution $\mathbf{R}$ was aspirated from the stomach.

Second series (36 rats) In this series the rats' stomachs were first filled with solution I (the same as solution T, except for the addition of one of the inhibitors in alternative concentrations); p-chloromercuribenzoate was used in concentrations of 2.5 or $25 \mathrm{mM}$ (12 rats), iodoacetamide in concentrations of 8 or $80 \mathrm{mM}$ (12 rats), and n-ethyl-maleimide in concentrations of 2 or $20 \mathrm{mM}$ (12 rats), instead of solution $T$.

In both series the $p \mathrm{H}$, the concentration of phenol red, and the quantity of hydrochloric acid secreted were measured at the end of the experiment. The $p \mathrm{H}$ was determined on a $p \mathrm{H}$ meter with glass and calomel electrodes; the concentration of phenol red was measured with a Coleman spectrophotometer at $560 \mu$, and the acidity by titration against $0.01 \mathrm{~N} \mathrm{NaOH}$. The total volume of gastric secretion is equal to the volume of fluid which passed through the pylorus during the experiment (vpp) plus the volume of gastric fluid at the end of the experiment minus $8 \mathrm{ml}$. (the volume of solution R). The volume of fluid passing through the pylorus (vpp) is calculated from the following formula:

$$
\mathrm{vpp}=\frac{\frac{Q-\left(\mathbf{Q}^{\prime}+W\right)}{\mathrm{C}+\mathbf{C}^{\prime}}}{2}
$$

where $Q=$ quantity of phenol red before intubation, $\mathrm{Q}^{\prime}=$ quantity of phenol after $45 \mathrm{~min} ., \mathrm{W}=$ quantity of phenol in washing after $45 \mathrm{~min}$., $\mathrm{C}=$ concentration of phenol red before intubation, and $\mathbf{C}^{\prime}=$ concentration of phenol red after $45 \mathrm{~min}$.

HISTOENZYMATIC STUDY OF GASTRIC MUCOSA IN RATS AFTER BLOCKAGE OF ACID SECRETION IN VIVO BY THE INHIBITORS To investigate histochemically the effect of p-chloromercuribenzoate, iodoacetamide, and n-ethylmaleimide on the enzymatic activity of the gastric mucosa of rats in which the acid secretion had been blocked by intubation of these inhibitors into the stomach lumen, the rats from experiment 3 were sacrificed at the end of the test. Tissue sampling and histochemical methods were the same as in experiment 1 . However, for reasons which will be explained later on, we used both standard concentrations of substrate and a ten-fold smaller concentrations of the latter. The results were compared with those from two sets of control rats of which five rats were treated with solution $T$ and sacrificed after 15 minutes and five rats were given solution $\mathrm{T}$, and then an injection of histamine and solution $\mathbf{R}$.

\section{RESULTS}

HISTOENZYMATIC STUDY OF THE GASTRIC MUCOSA OF THE RAT The distribution of the various enzyme systems is shown in Table I. We have expressed our results in terms of density of staining, using five degrees, namely, very heavy ++++ , heavy +++ , moderate ++ , light + , faint \pm , no activity 0 .

\section{TABLE I}

ENZYMATIC DISTRIBUTION IN THE STOMACH MUCOSA OF NORMAL RATS

\begin{tabular}{lccl} 
Enzymes & $\begin{array}{c}\text { Mucosal Neck } \\
\text { Cells }\end{array}$ & Chief Cells & Parietal Cells \\
\hline SDH & + & \pm & ++++ \\
BDH & \pm & \pm & ++++ \\
LDH & ++ & + & ++++ \\
ICDH & \pm & \pm & ++++ \\
G-6PD & + & \pm & +++ \\
a-GPD & \pm & + & +++ \\
ATPase & + & + & ++++ \\
TPN & + & + & +++ \\
DPN & + & ++ & ++++ \\
Est $\boldsymbol{a}$ & \pm & 0 & ++ \\
AlkP & 0 & + & ++ \\
AcP & \pm & &
\end{tabular}

The different types of cells in the gastric mucosa of normal rats show an enzymatic activity which differentiates them from each other.

Alkaline phosphatase None was present in any mucosal cells.

Acid phosphatase No staining was seen in mucous neck cells, light staining in the chief cells, and moderate staining throughout the cytoplasm of parietal cells.

$\alpha$ Esterase There was faint staining in the mucous neck cells and moderate staining of chief and parietal cells.

Succinate Light staining was seen in mucous neck cells, faint staining in the chief cells, and very heavy staining of parietal cells (Fig. 3).

Isocitrate and hydroxybutyrate Faint staining was seen in mucous neck cells and chief cells and very heavy staining in the parietal cells.

Lactate Staining of mucous neck cells was moderate, light in the chief cells, and very heavy in the parietal cells.

Glucose-6-phosphate Light staining in the mucous neck cells was seen, faint staining in the chief cells, and heavy staining in the parietal cells.

$\alpha$-Glycerophosphate Staining was faint in the mucous neck cells and in the chief cells, and heavy in the parietal cells.

Adenosinetriphosphate No staining was seen in the 


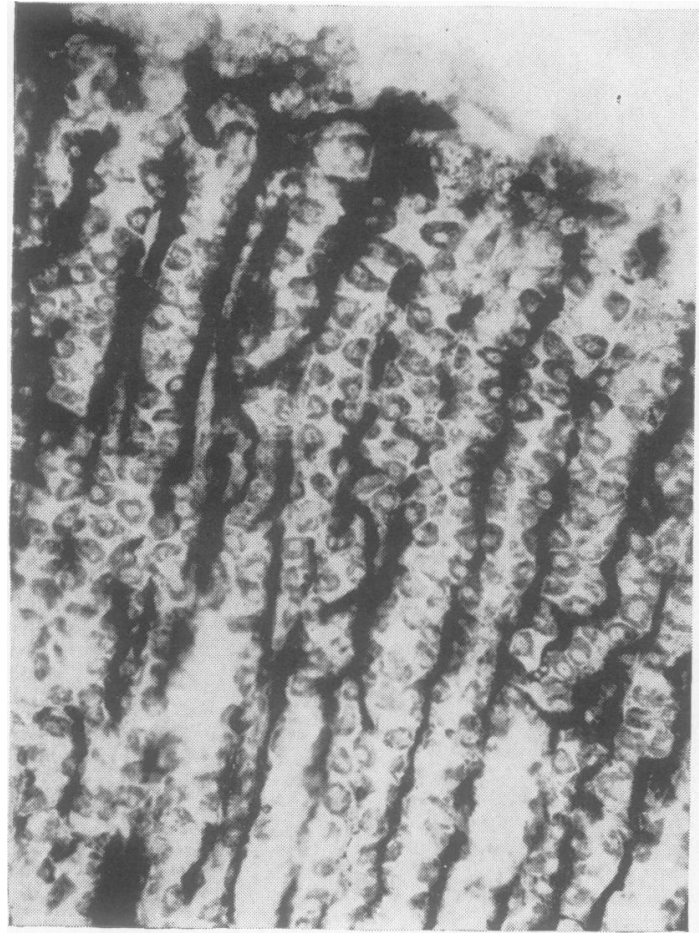

FIG. 1.

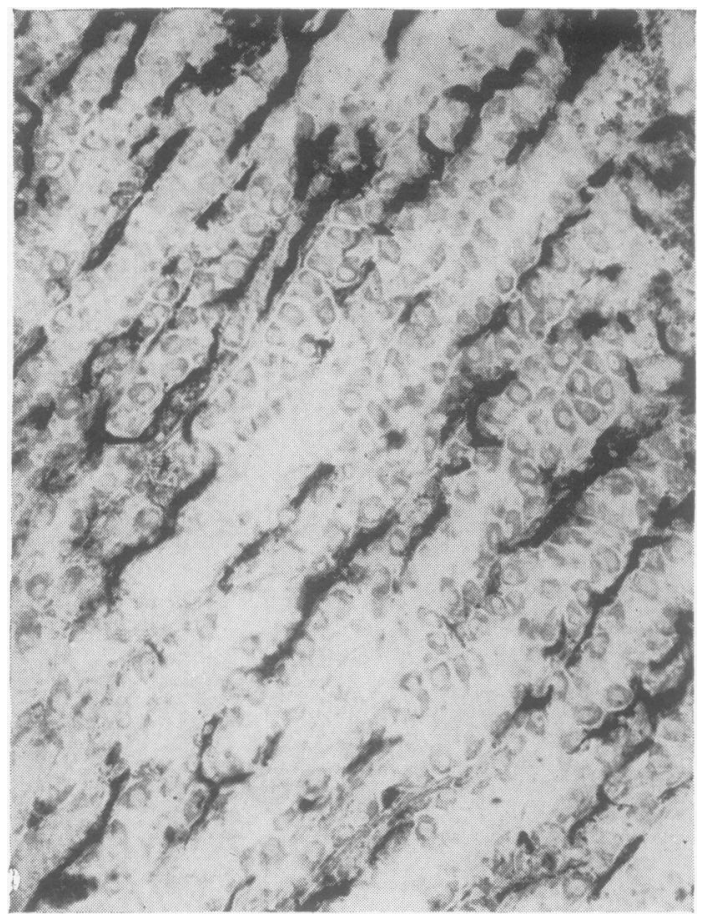

FIG. 2.

FIG. 1. Stomach of normal rat (adenosine triphosphatase) showing striking activity of the parietal cells. $\quad \times 320$.

FIG. 2. Stomach of normal rat (adenosine triphosphatase) after the effect of PCMB at 2.5 mM concentration showing distinct diminution of parietal cell activity. $\times 320$.

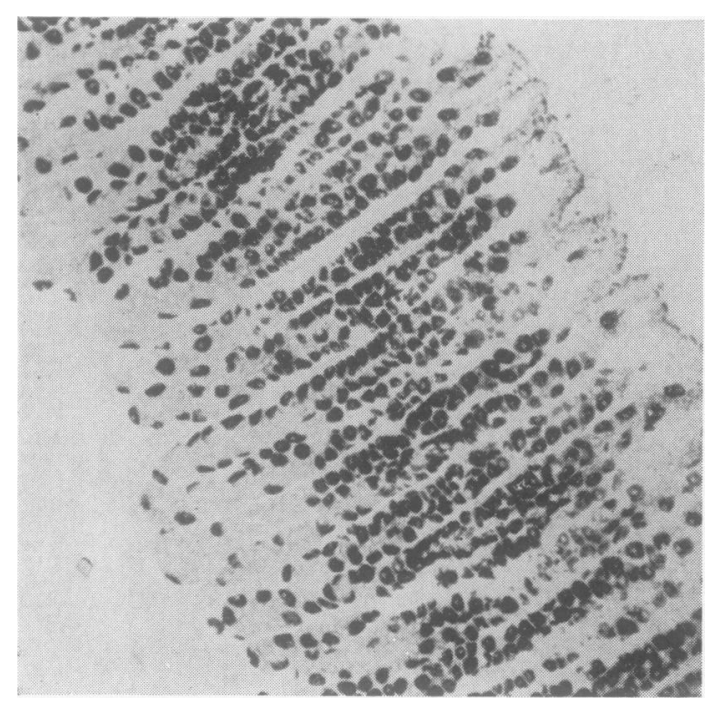

FIG. 3. Stomach of normal rat (succinie dehydrogenase) showing striking activity of the parietal cells. $\times 160$.

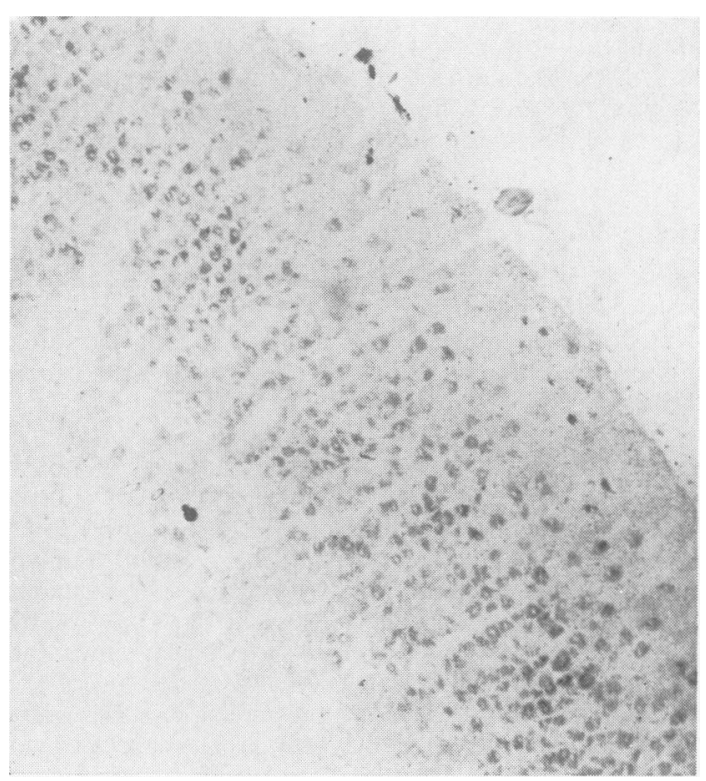

FIG. 4. Stomach of normal rat (succinic dehydrogenase) after the effect of PCMB at $0.75 \mathrm{mM}$. concentration showing diminished activity of the parietal cell. $\quad \times 160$. 
TABLE II

ENZYMATIC ACTIVITY OF THE PARIETAL CELLS OF THE GASTRIC MUCOSA IN NORMAL AND IN RATS TREATED BY INHIBITORS APPLIED IN VITRO OR ADDED TO THE SUBSTRATE

Inhibitor (Concentration in $\mathrm{mMol}$ )

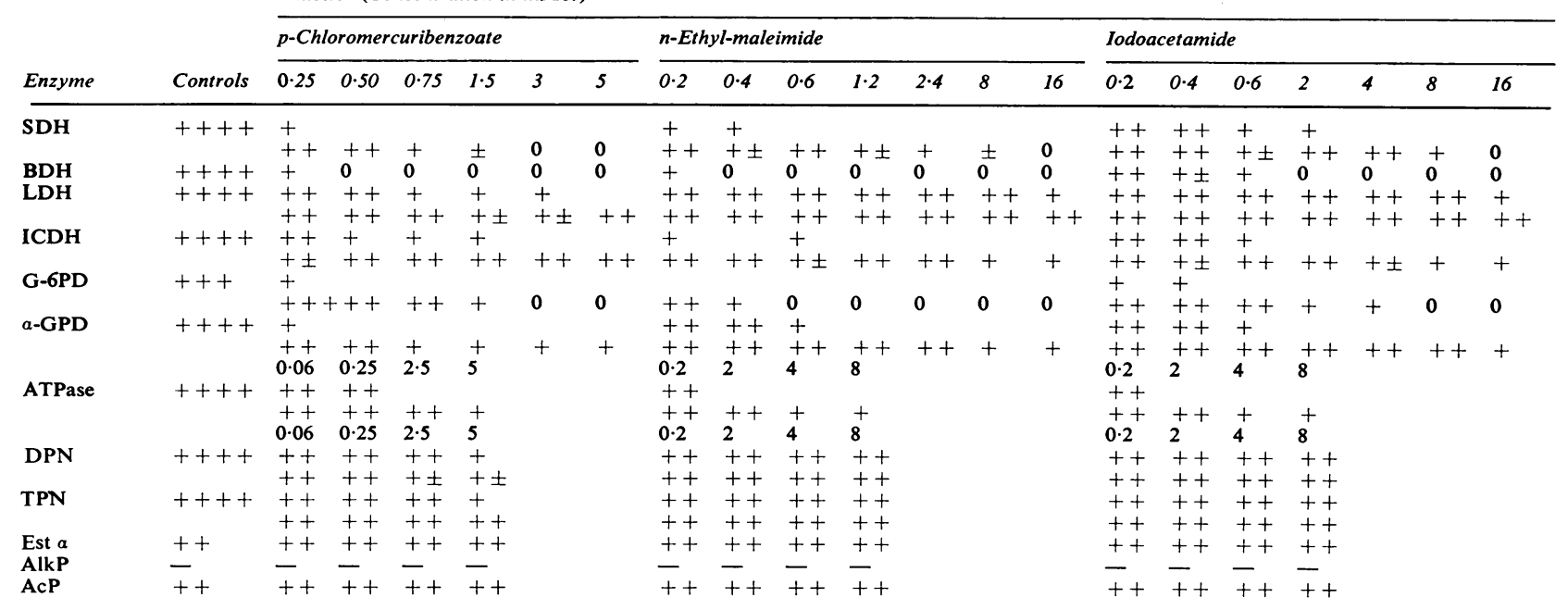

mucous neck cells and in the chief cells, but very heavy staining in the parietal cells (Fig. 1).

$T P N$ No staining was seen in the mucous neck cells and chief cells, but heavy staining in the parietal cells.

$D P N$ There was no staining in the mucous neck cells and chief cells, but very heavy staining in the parietal cells.

EFFECT OF THE INHIBITORS ON THE ENZYME ACTIVITY OF THE GASTRIC MUCOSA IN VITRO All the enzyme inhibitors - p-chloromercuribenzoate, iodoacetamide, n-ethyl-maleimide - whether applied before incubation or added to the incubation medium inhibit certain enzymes in vitro (Table II), the inhibition varying according to the concentration of the inhibitor and the nature of the enzyme. It was more marked with p-chloromercuri-benzoate than with the two other inhibitors. Small concentrations of the inhibitors $(0.5 \mathrm{mM}$ of p-chloromercuribenzoate and $0.6 \mathrm{mM}$ of the other two) already had a striking effect on SDH (Fig. 4), BDH, G-6PD, and $\alpha$-GPD; the ICDH and ATPase (Fig. 2) were inhibited by a slightly higher concentration of the three inhibitors; DPN, TPN, and LDH were little affected by even high concentrations of p-chloromercuribenzoate $(5 \mathrm{mM})$, n-ethyl-maleimide $(16 \mathrm{mM})$, and iodoacetamide $(16 \mathrm{mM})$. The $\alpha$-esterase and the ACP were unaffected by any of the inhibitory compounds.

EFFECT OF THE INHIBITORS ON HCL SECRETION PRODUCED BY HISTAMINE STIMULATION As shown in
Table III, the inhibitors in the two concentrations employed almost completely inhibited the secretion of hydrochloric acid produced by subcutaneous injection of histamine.

TABLE III

EFFECT ON ACID SECRETION OF THE INHIBITORS APPLIED IN VIVO ON THE STOMACH AFTER STIMULATION BY SUBCUTANEOUS HISTAMINE

\begin{tabular}{lcccc} 
Rat & $\mathrm{pH}$ & $\begin{array}{l}\text { Standard } \\
\text { Deviation }\end{array}$ & $\begin{array}{l}\text { Amount of } \\
\text { Acid } \\
\text { Secreted }\end{array}$ & $\begin{array}{l}\text { Standard } \\
\text { Deviation }\end{array}$ \\
\hline Control & 2.92 & 0.439 & 250 & 39.81 \\
$\begin{array}{l}\text { After p-chloromercuri- } \\
\quad \text { benzoate }\end{array}$ & $7 \cdot 7$ & 0.431 & 7.1 & 1.91 \\
$\begin{array}{l}\text { After iodoacetamide } \\
\text { After n-ethyl-maleimide }\end{array}$ & 7.5 & 0.44 & 6.6 & 1.87 \\
& 7.5 & 0.438 & 6.7 & 1.93
\end{tabular}

ENZYME HISTOCHEMISTRY OF THE GASTRIC MUCOSA AFTER BLOCKAGE OF HCL SECRETION BY GASTRIC INCUBATION OF THE INHIBITORS With standard concentrations of substrate no difference was observed in the enzyme activity of gastric mucosa between rats which had received p-chloromercuribenzoate, iodoacetamide, or n-ethyl-maleimide, and those treated with the control solution not containing inhibitors. On the contrary, with incubation media containing a ten-fold smaller concentration of substrate a distinct diminution was observed in the rats in which the acid secretion had been blocked by intragastric intubation of inhibitors against those intubated with the control solutions. Conversely, inhibition was present with standard 
TABLE IV

EFFECT OF THE INHIBITION IN VIVO ON THE HISTOENZYMATIC ACTIVITY OF THE PARIETAL CELLS OF THE STOMACH ${ }^{1}$

\begin{tabular}{|c|c|c|c|c|c|c|c|c|}
\hline \multirow[b]{3}{*}{ Enzyme } & \multicolumn{4}{|c|}{$\begin{array}{l}\text { p-Chloromercuribenzoate }(2 \cdot 5 \mathrm{mM}) \\
\text { Iodoacetamide }(8 \mathrm{mM}), \mathrm{n} \text {-Ethyl-maleimide }(2 \mathrm{mM}) \\
\text { Given by Stomach Tubing }\end{array}$} & \multicolumn{4}{|c|}{$\begin{array}{l}\text { p-Chloromercuribenzoate }(25 \mathrm{mM}) \text {, } \\
\text { Iodoacetamide }(80 \mathrm{mM}), \mathrm{n} \text {-Ethyl-maleimide }(20 \mathrm{mM}) \\
\text { Given by Stomach Tubing }\end{array}$} \\
\hline & \multicolumn{2}{|c|}{$\begin{array}{l}\text { Standard Concentration } \\
\text { of Substrate }\end{array}$} & \multicolumn{2}{|c|}{$\begin{array}{l}\text { Standard Concentration } \\
\text { of Substrate/10 }\end{array}$} & \multicolumn{2}{|c|}{$\begin{array}{l}\text { Standard Concentration } \\
\text { of Substrate }\end{array}$} & \multicolumn{2}{|c|}{$\begin{array}{l}\text { Standard Concentration } \\
\text { of Substrate/10 }\end{array}$} \\
\hline & $\begin{array}{l}\text { Control } \\
\text { Rats }\end{array}$ & $\begin{array}{l}\text { Treated } \\
\text { Rats }\end{array}$ & $\begin{array}{l}\text { Control } \\
\text { Rats }\end{array}$ & $\begin{array}{l}\text { Treated } \\
\text { Rats }\end{array}$ & $\begin{array}{l}\text { Control } \\
\text { Rats }\end{array}$ & $\begin{array}{l}\text { Treated } \\
\text { Rats }\end{array}$ & $\begin{array}{l}\text { Control } \\
\text { Rats }\end{array}$ & $\begin{array}{l}\text { Treated } \\
\text { Rats }\end{array}$ \\
\hline $\begin{array}{l}\text { SDH } \\
\text { BDH } \\
\text { LDH } \\
\text { ICDH } \\
\text { G-6PD } \\
\text { a-GPD } \\
\text { ATPase } \\
\text { TPN } \\
\text { DPN } \\
\text { Est } a \\
\text { AlkP } \\
\text { AcP }\end{array}$ & $\begin{array}{l}++++ \\
++++ \\
++++ \\
++++ \\
++++ \\
++++ \\
++++ \\
++++ \\
++++ \\
++ \\
0 \\
++\end{array}$ & $\begin{array}{l}++++ \\
++++ \\
++++ \\
++++ \\
++++ \\
++++ \\
++++ \\
++++ \\
++++ \\
++ \\
0 \\
++\end{array}$ & $\begin{array}{l}++ \\
++ \\
++ \\
++ \\
++ \\
++ \\
++ \\
++ \\
++ \\
+ \\
0 \\
+\end{array}$ & $\begin{array}{l}+ \\
+ \\
++ \\
+ \\
+ \\
+ \\
+ \\
++ \\
++ \\
+ \\
0 \\
+\end{array}$ & $\begin{array}{l}++++ \\
++++ \\
++++ \\
++++ \\
++++ \\
++++ \\
++++ \\
++++ \\
++++ \\
++ \\
0 \\
++\end{array}$ & $\begin{array}{l}++ \\
++ \\
++++ \\
++ \\
++ \\
++ \\
++ \\
++++ \\
++++ \\
++ \\
0 \\
++\end{array}$ & $\begin{array}{l}++ \\
++ \\
++ \\
++ \\
++ \\
++ \\
++ \\
++ \\
++ \\
+ \\
0 \\
+\end{array}$ & $\begin{array}{l}+ \\
+ \\
++ \\
+ \\
+ \\
+ \\
+ \\
++ \\
++ \\
+ \\
0 \\
+\end{array}$ \\
\hline
\end{tabular}

${ }^{1}$ The inhibition by p-chloromercuribenzoate is more marked than by n-ethyl-maleimide and even more by iodoacetamide, and to simplify the table, we omitted this difference.

concentrations of incubation media in histochemical preparations from rats intubated with a ten-fold stronger concentration of inhibitors (Table IV). No differences in the histochemical enzyme reactions of the gastric mucosa were found between histamineinjected and control rats.

\section{DISCUSSION}

Concerning the distribution of enzymes in the rat stomach our results are similar to those reported by Villarreal and Burgos (1955) and Niemi, Siurala, and Sundberg (1960). It seems to be almost the same as that in human gastric mucosa but in the latter the enzymatic activity is on the average weaker (Stoffels, 1964). Planteydt (1961) found only weak ATPase activity in human stomach, whereas Correira, Filipe, and Santos (1963) found none. Our findings of strong ATPase activity in the parietal cells is at variance with these authors', but the discrepancy can probably be attributed to the different technical procedures. It is well known that prolonged fixation, as used by these authors, destroys mitochondrial ATPase activity, whereas mitochondrial ATPase is at least partly preserved by the method of Wachstein et al. (1962).

We have been able to ascertain that six of the 12 enzymes which have been studied are depressed in vitro, even by weak concentrations of the three inhibitors, namely, SDH, BDH, ICDH, G-6PD ATPase, and $\alpha$-GPD. All these enzymes are -SH dependent (Boyer, Lardy, and Myrbäck, 1963) and the inhibition produced by the inhibitors under these conditions is readily understood on this basis.
Concerning the inhibition of gastric secretion produced in vivo by intubation with p-chloromercuribenzoate, n-ethyl-maleimide, and iodoacetamide, our results are comparable to those of Hollander (1956) in the dog.

The lack of inhibition of the enzyme activity in histochemical preparations of the gastric mucosa of rats in which the acid secretion had been blocked by gastric intubation of small concentrations of p-chloromercuribenzoate $(2.5 \mathrm{mM})$, n-ethylmaleimide $(2 \mathrm{mM})$, and iodoacetamide $(8 \mathrm{mM})$ appeared disappointing at first sight. However, this inhibition clearly showed when instead of standard concentrations of substrate, ten-fold smaller concentrations were used. With standard concentrations of substrate, a ten-fold stronger concentration of inhibitors in the gastrically intubated solution was required to produce inhibition on histochemical slides. These results are predictable if the kinetic mechanism of enzymatic inhibition is taken into account. The inhibition induced by p-chloromercuribenzoate, iodoacetamide, and n-ethyl-maleimide is a non-competitive inhibition which follows the modified formula of Lineweaver and Burk.

$$
\frac{1}{\mathrm{~V}}=\left[1+\frac{(\mathrm{I})}{\mathrm{K}}\right] \frac{1}{\mathrm{~V}}+\left[\frac{\mathrm{Km}}{\mathrm{V}} \frac{1}{(\mathbf{S})}\right]
$$

$\mathbf{v}=$ speed of reaction

(I) $=$ concentration of the inhibitor

$\mathrm{K}=$ constant of dissociation of the enzyme inhibitor complex

$\mathrm{V}=$ maximal speed of reaction

$\mathrm{Km}=$ constant of Michaelis-Menten

(S) $=$ concentration of substrate 
The blockage of acid secretion in rats after gastric intubation with the inhibitors indicates that the quantity of inhibitor which penetrates into the parietal cells is sufficient to block the enzyme reaction with the endogenous substrate. In vivo the relative amount of inhibitor to the amount of endogenous substrate appears sufficently high to arrest the reaction. In vitro, however, the standard histochemical methods use higher concentrations of substrate. The relative amounts of inhibitor and of substrate are decreased to a level which no longer allows the demonstration of the inhibition which was observed in vivo. When ten-fold stronger concentrations of inhibitors in the intubation solution or ten-fold smaller concentrations of substrate in the incubation medium were used this relation was restored to a level which permitted the demonstration of the inhibition.

The enzymes which are inhibited by p-chloromercuribenzoate, n-ethyl-maleimide, and iodoacetamide all play an important part, in one way or another, in the energy-producing metabolism of the parietal cells. It has been demonstrated (Hogben, 1951; Rehm and Dennis, 1957) that $\mathrm{H}+$ and $\mathrm{Cl}+$ are both transported into the lumen of the stomach against electrochemical gradients, thereby necessitating a great deal of energy. It could well be therefore that these inhibitors suppress the secretion of acid in the gastric mucosa by blocking the energy-producing metabolic pathways in the parietal cells.

On the other hand it cannot be excluded that p-chloromercuribenzoate, n-ethyl-maleimide, and iodoacetamide also act in a more specific enzyme system involved in acid secretion. Davenport and Chavré (1956) and Vitale, Jankelson, Connors, Hegsted, and Zamcheck (1956) have produced evidence that the succinoxidase system plays an important role in acid secretion. Succinoxidase is a multi-enzyme system concerned in the dehydrogenation of succinate into fumarate, with the production of two $\mathrm{H}+$. Antimycin A blocks the succinoxidase system and also inhibits acid secretion in the stomach. Succinic dehydrogenase, which is SH-dependent and inhibited by $\mathrm{p}$-chloromercuribenzoate, n-ethyl maleimide, and iodoacetamide, is part of this system. Further studies will therefore be required to determine the relative importance of non-specific energyproducing metabolic pathways and of the succinic oxidase system for the production of hydrochloric acid by gastric mucosa.

\section{SUMMARY}

The effect of p-chloromercuribenzoate, n-ethylmaleimide, and iodoacetamide on the acid secretion and the enzyme activity of the gastric mucosa was studied in rats. The parietal cells of the gastric mucosa show strong activity in succinic dehydrogenase, $\beta$-hydroxybutyrate dehydrogenase, isocitric dehydrogenase, glucose-6-phosphate dehydrogenase, $\alpha$ glycerophosphase dehydrogenase, and mitochondrial adenosine triphosphatase (ATPase).

The inhibitors studied markedly inhibited these activities in vitro. The same type of inhibition was observed in histochemical preparations of gastric mucosa from rats in which the acid secretion had been blocked by intubation into the stomach lumen of p-chloromercuribenzoate, n-ethyl-maleimide, and iodoacetamide.

Their inhibitory effect on acid secretion by the stomach mucosa could be the result of their blocking the energy-producing metabolism of the parietal cells. Another explanation is that they interfere with the succinic oxidase system, which has been shown to play a role in the secretion of acid by the parietal cells.

The skilful technical assistance of Mrs. M. Couck and M. L. Baum is gratefully acknowledged.

\section{REFERENCES}

Boyer, P. D., Lardy, H., and Myrbäck, K. (1963). The Enzymes, Vol. 7. Academic Press, New York.

Correira, J. P., Filipe, M. I., and Santos, J. C. (1963). Histochemistry of the gastric mucosa. Gut, 4, 68-76.

Davenport, H. W., Chavré, V. G., and Davenport, V. D. (1954). Inhibition of gastric acid secretion by p-chloromercuribenzoate. Amer. J. Physiol., 177, 418-424.

$-,-1,-(1955)$. Inhibition of gastric acid secretion by iodoacetate amide and n-ethyl-maleimide. Ibid. 182, 221-226. - (1956). Succinoxidase and gastric acid secretion. Ibid., 187, 227-230.

Gomori, G. (1952). Lead nitrate method for acid phosphatase. In Microscopic Histochemistry, p. 193-194. University of Chicago Press, Chicago.

Hogben, C. A. (1951). The chloride transport system of the gastric mucosa. Proc. nat. Acad. Sci. (Wash.), 37, 393-395.

Hollander, F. (1956). Inhibition of gastric secretion in vivo by iodoacetamide and n-ethyl-maleimide. Amer. J. Physiol., 187, 231-236.

Nachlas, M. M., Tsou, K. C., De Souza, E., Cheng, C. S., and Seligman, A. M. (1957). Cytochemical demonstration of succinic dehydrogenase by the use of a new p-nitrophenyl substituted ditetrazole. J. Histochem. Cytochem., 5, 420-436.

Niemi, M., Siurala, M., and Sundberg, L. (1960). The distribution of cytochemically demonstrable diphosphopyridine nucleotide diaphorase and succinic and lactic dehydrogenases in the normal human gastric mucosa. Acta path. microbiol. scand., 48, 323-327.

Pearse, A. G. E. (1960). Histochemistry, Theoretical and Applied, 2nd ed., p. 886. Churchill, London.

Planteydt, H. (1961). Maag en maagcarcinoom. Thesis. N.V. Drukkerij Leyden.

Rehm, W. S., and Dennis, W. H. (1957). In Metabolic Aspects of Transport across Cell Membranes, edited by Q. R. Murphy, p. 303, University of Wisconsin Press, Madison.

Scarpelli, D. G., Hess, R., and Pearse, A. G. E. (1958). The cytochemical localization of oxidative enzymes. I. Diphosphopyridine nucleotide diaphorase and triphosphopyridine nucleotide diaphorase. J. biophys. biochem. Cytol., 4, 747-752. Stoffels, G. (1964). Unpublished observations.

Thornton, G. H. M., and Clifton, J. A. (1959). Estimation of gastric hydrochloric acid secretion in rats by a test meal technique. Amer. J. Physiol., 197, 263-268. 
Valberg, L. S., and Wetts, L. J. (1961). The histamine test meal in the rat. Gut, 2, 32-36.

Villarreal, R., and Burgos, M. H. (1955). A correlated biochemical and histochemical study of succinic dehydrogenase activity in the gastric mucosa of the rat and frog. J. cell. comp. Physiol. 46, 327-339.

Vitale, J. J., Jankelson, O. M., Connors, P., Hegsted, D. M., and Zamcheck, N. (1956). Succinic and malic oxidase in gastric hydrochloric acid production. Amer. J. Physiol., 187, 427-431.

Wachstein, M., Bradshaw, M., and Ortiz, J. M. (1962). Histochemical demonstration of mitochondrial adenosine triphosphatase activity in tissue section. J. Histochem. Cytochem., 10, 65-74.

- and Meisel, E. (1957). Histochemistry of hepatic phosphatases at a physiologic $p \mathrm{H}$, with special reference to the demonstration of bile canaliculi. Amer. J. clin. Path., 27, 13-23.

Wattenberg, L. W., and Leong, J. L. (1960). Effect of coenzyme $Q_{10}$ and menadione on succinic dehydrogenase activity as measured by tetrazolium salt reduction. J. Histochem. Cytochem., 8, 296-303. 